\title{
CRYSTAL SIZE DISTRIBUTION OF AMPHIBOLE AND PLAGIOCLASE FROM ZANBIL ADAKITIC DACITES, URMIA- IRAN: EVIDENCE FOR MAGMA MIXING AND TEXTURAL COARSENING
}

\author{
Monir MODJARRAD * and Saber SHAYKHBAGLOU
}

Department of Geology, Faculty of Sciences, University of Urmia, 57153165, Urmia, Iran

*Corresponding author's e-mail: m.modjarrad@urmia.ac.ir

\section{ARTICLE INFO}

\section{Article history:}

Received 25 May 2015

Accepted 9 July 2015

Available online 21 September 2015

\section{Keywords:}

Crystal size distribution (CSD)

Residence time

Magma mixing

Textural coarsening

Zanbil, Iran

\begin{abstract}
In this contribution the crystal size distribution (CSD) of amphibole and plagioclase from the Zanbil adakitic dacites of Iran were measured for a series of 20 samples spanning most of the exposed dome. Growth histories, residence time and textural features were studied at the rocks. All amphiboles and plagioclases show non-linear concave up CSD trends, forming a population density with two distinct parts. It can be modeled by mixing two crystal populations, here named fine grains, with intercept values of approximately $12 \mathrm{~cm}^{-4}$ for amphiboles and $7 \mathrm{~cm}^{-4}$ for plagioclase and phenocrysts, with intercept values of $8 \mathrm{~cm}^{-4}$ for amphibole and $4 \mathrm{~cm}^{-4}$ for plagioclase, each with overlapping linear CSDs. The plagioclase CSDs characterized with an individual flat part as a result of textural coarsening. The latest data show that plagioclase nucleation sites are lower than amphiboles, but growth was noticeable. The magmas bearing the fine grains and phenocrysts started to crystallize at 15-20 and 30-38 years, respectively, before each eruption, assuming a growth rate of $10^{-10} \mathrm{~cm} / \mathrm{s}$. Phenocrysts crystallized during longer residence times. Subsequently, new magma containing few or no crystals was introduced and the fine grains crystallized from the mixed magma. Eruption followed 15-20 years after mixing. Such a model suggests that some porphyritic volcanic rocks erupted from shallow magma chambers that were never fully emptied.
\end{abstract}

\section{INTRODUCTION}

Magmatic textures provide an insufficiently explored tool to interpret physical processes and environmental variables that drive differentiation and crystallization in magma chambers (Spillar and Dolejz, 2013).

One of the most discussed matters in igneous petrology is the question of how magmatic rocks solidify or densify (in materials science). Solidification can also be thought of as development of textures (Higgins, 2002). Early petrology was certainly dominated by textural observations. Recent advances in the theory and practice of quantification of textures in igneous rocks (e.g. Marsh, 1998; Higgins, 1998; 2000) indicate that it is now possible to examine some of the igneous suites in this way.

Volcanic products can be used to reconstruct magma chamber processes and are generally studied geochemically and texturally. However, it is possible to quantify certain aspects of rock textures and the most common technique is by determining crystal size distributions (CSD). This approach can offer a fresh and complementary way of looking at processes in magma chambers (Marsh, 1988; 1998; Higgins and Roberge, 2003). The method has been used to study many igneous processes such as nucleation, growth and magma mixing (e.g. Cashman and Marsh, 1988; Higgins, 1996; 1998). Solidification, crystallization and existence of glass are major problems in petrology. In addition, magma temperature and composition can be changed by mixing with a hotter magma (Sparks et al., 1977; Murphy et al., 2000; Couch et al., 2001) whereby small crystals may dissolve and large crystals grow (textural coarsening, known as Ostwald ripening). In literature, CSD studies using amphibole crystals are rare (Higgins and Roberge, 2003; Nkono et al., 2006; Modjarrad, 2015a), and several studies have focused on plagioclase nucleation and growth rate (e.g. Castro et al., 2003; Mock and Jerram, 2005; Cashman, 1992; Wilhelm and Worner, 1996). CSD studies of metamorphic rocks are uncommon (e.g. Moazzen and Modjarrad, 2005; Modjarrad and Shaykhbaglou, 2015), but some pioneering works exist (e.g. Kretz, 1966). The crystal size data can be used to determine magma residence times, crystallization history and mixing events between different crystal populations (Yu et al., 2012; 2014; Zellmer et al., 1999; Cooper and Reid, 2003).

The aim of this study is to understand how the volcanic rocks of the Zanbil area solidified, or at least to identify the most important processes during volcanism. In particular, we want to assess the relative roles of residence time, textural coarsening (Ostwald Ripening) and the refilling of magma in to chamber and their interactions. We will use variations in textural parents, particularly CSDs to understand these processes. It shows that CSD analysis can be used to establish residence times of crystal populations and elucidate the mechanics of magma dynamics. 


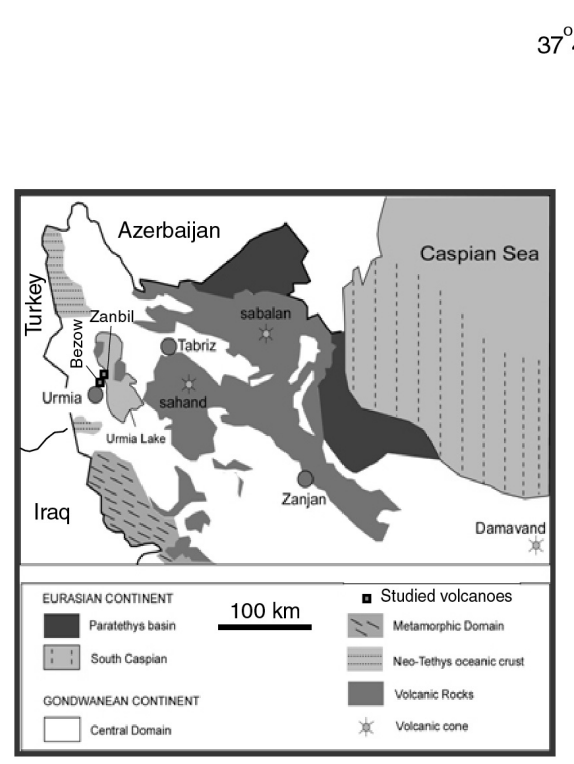

$45^{\circ} 12^{\prime}$

$45^{\circ} 17^{\prime}$
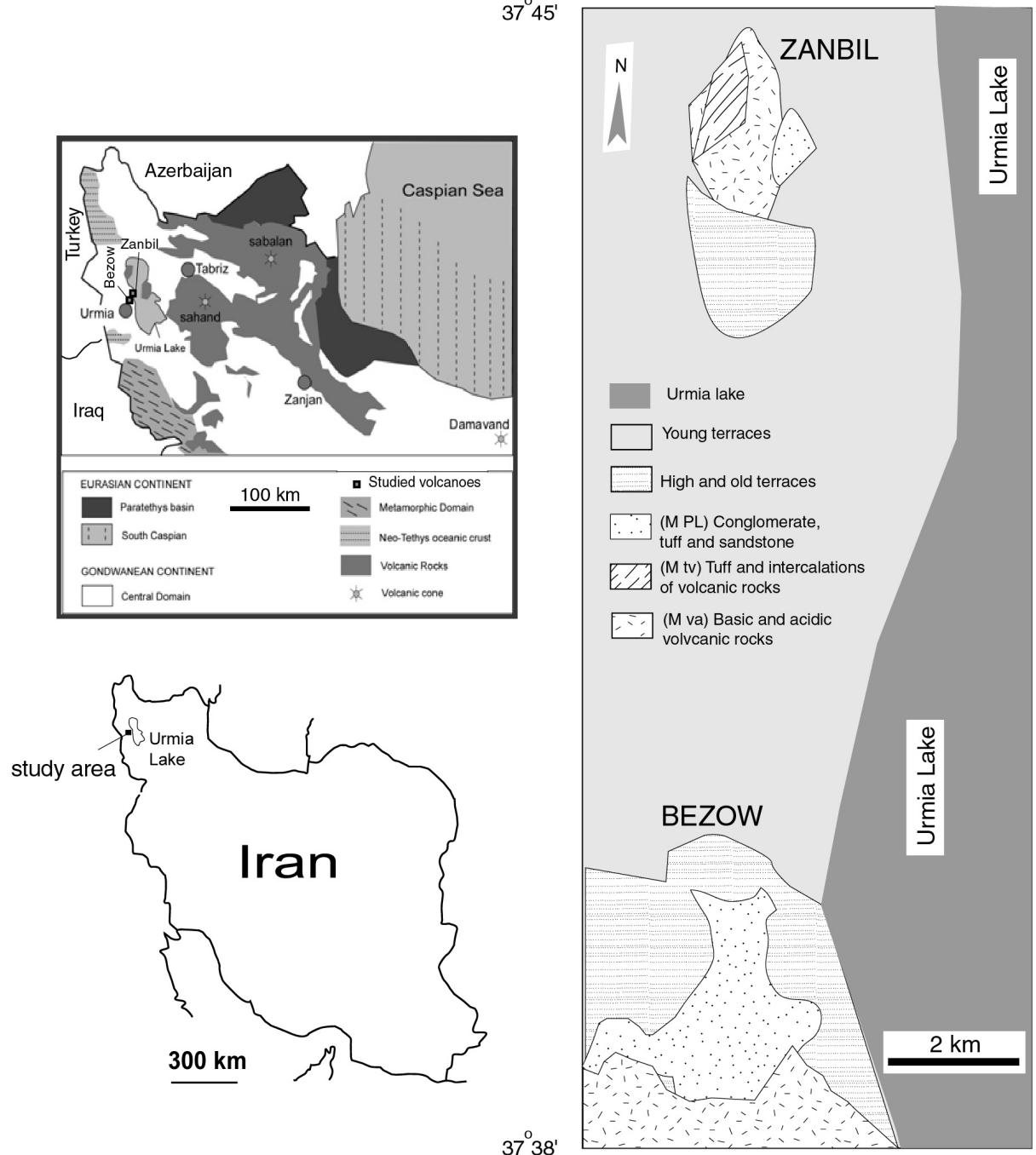

Fig. 1 Simplified geological map of the area including the geological zones of Iran (after Aghanabati, 2004).

\section{GEOLOGICAL OVERVIEW OF THE ZANBIL ADAKITIC DACITES}

The study area is located at the west side of Urmia Lake and close to Urmia Township and is situated in the Central Iran geological zone, based upon structural divisions of Iran (Aghanabati, 2004), at the in northwestern Iran (Fig. 1).

To the east lies the dacitic and adakitic Sahand Volcano and it is possible that the Bezow dome of similar affinity (Modjarrad, 2015a; 2015b) is part of the volcanic complex (Fig. 1). Different pyroclastic and volcanic products (acidic to intermediate composition) are exposed, but dacite predominates. Geochemical studies show that the rocks are dacites, of I-type and calcalkaline and erupted in a volcanic arc (VAG) setting (Modjarrad, 2015a). Detailed studies have shown that the rocks are high-SiO${ }_{2}$ adakites (HSA) and that the parental magma was generated as a result of subduction and partial melting of an oceanic slab and its overlying sediments and have a post-collisional affinity (Kohnavard, 2015). All geochemical characteristics of adakite found in literature also apply to the Zanbil adakites, such as: $\mathrm{Sr}>400 \mathrm{ppm}, \mathrm{MgO}<3 \%, \mathrm{Al}_{2} \mathrm{O}_{3}>15 \%, \mathrm{SiO}_{2}>56 \%$, enrichment in light rare earth elements (LREE) and large lithophile elements (LILE), depletion in heavy REE (HREE) and $\mathrm{Y}$, and high $\mathrm{La} / \mathrm{Yb}>20$ and $\mathrm{Sr} / \mathrm{Y}>40$ ratios (Kohnavard, 2015). The rocks are very similar and comparable in geochemistry to Bezow adakitic dacites (Modjarrad, 2015a). The volcanic rocks of Zanbil have not been described before in the international geological literature. The major minerals are plagioclase and amphibole which are set in a microlitic to hyaline matrix. Poikilitic and overgrowth textures on plagioclase are common. The most common megacryst phase is plagioclase, followed by amphibole, all set in a fine-grained matrix (Fig. 2). Amphibole grains make up approximately $4.5 \%$ and plagioclase $10 \%$ of the rock samples and are divided in to two populations: fine grains and phenocrysts (Fig. 2). This study attempts to explain how the two groups are formed by CSD studies on the plagioclase and amphibole. 

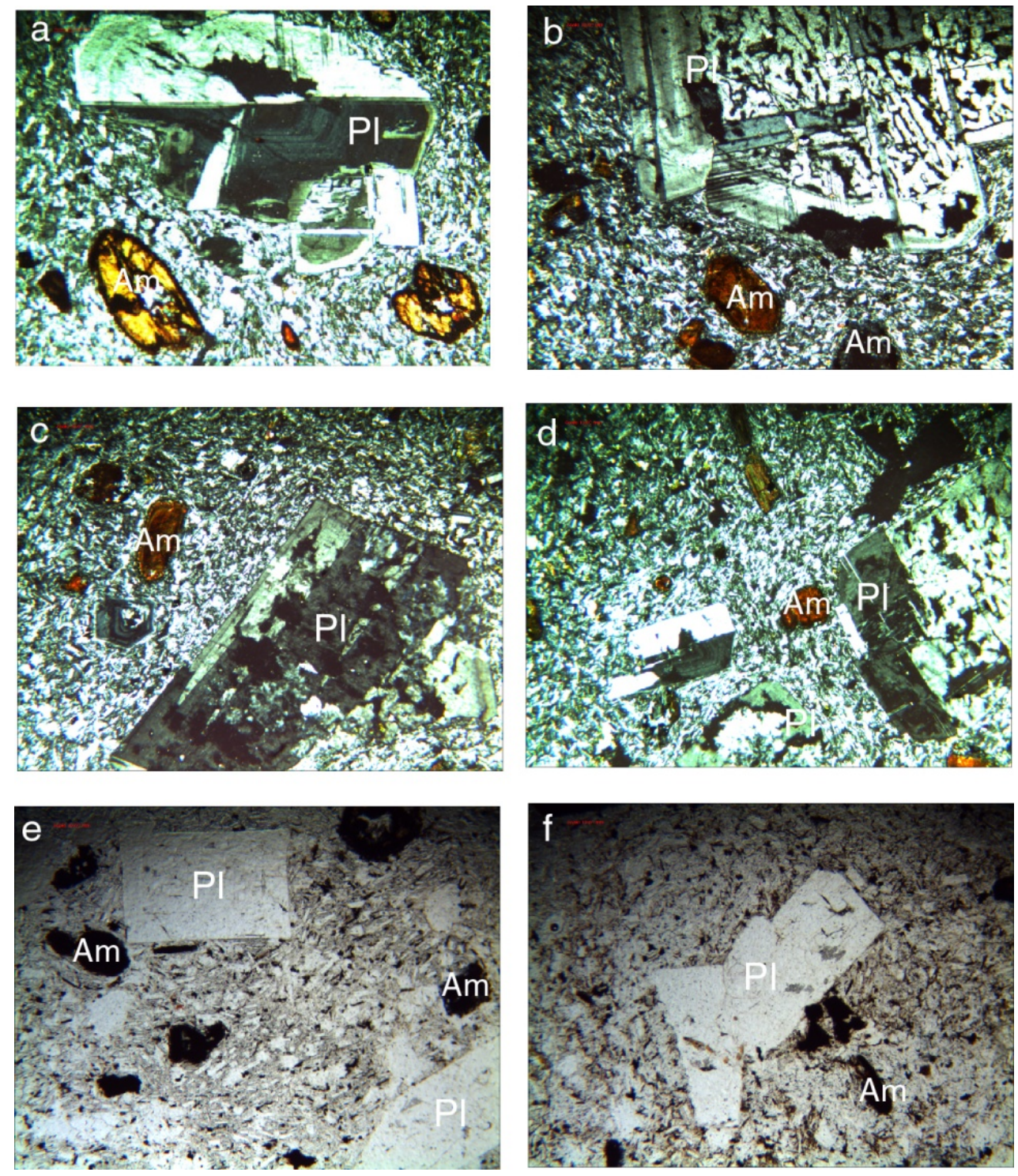

Fig. 2 Photomicrographs of Zanbil dacites. Coarse amphibole and plagioclase as phenocrysts and fine crystals at the dacite matrix (all in XPL just e and $f$ are in PPL). Note the euhedral phenocrysts and differences in sizes. Width of view $2.5 \mathrm{~mm}$ for all cases.

\section{CRYSTAL SIZE DISTRIBUTION (CSD)}

If we want to understand solidification of igneous rocks, then we must quantify parameters, such as crystal size, and apply the modeling of textures. CSDs have been used to model magma chamber dynamics (Mangan, 1990) and detailed eruptive histories (Hammer et al., 1999). Textural studies in igneous petrology flourished in the $19^{\text {th }}$ century, following the development of the petrographic microscope (Higgins, 2000). CSD studies of igneous and metamorphic rocks have become more popular recently partly because researchers realized that it is a quantitative method of looking at igneous processes that is complementary to geochemical studies (e.g. Cashman, 1990; 2002; Waters and Boudrea, 1996; Zieg and Marsh, 2002). A further reason may be the recent availability of simple methods of calculating CSDs from measurements in two dimensions, such as thin sections (e.g. Peterson, 1996).

\section{METHOD}

The CSD method is expressed as a function of size and used for modeling crystallization during magmatic processes (Marsh, 1988). A theory has been elaborated by Marsh (1988) and Cashman and Marsh (1988) to account for the distribution of crystal sizes in rocks: the natural logarithm of the crystal population density is as a function of crystal length. This correlation is generally called CSD. The core of CSD analysis is a semi-logarithmic plot of the population density number of crystals of a given size per unit volume vs size (Castro et al., 2003). The CSD method provides fundamental insight to time variations of nucleation and growth and also to the dynamics of magmatic systems (Marsh, 1988). The 


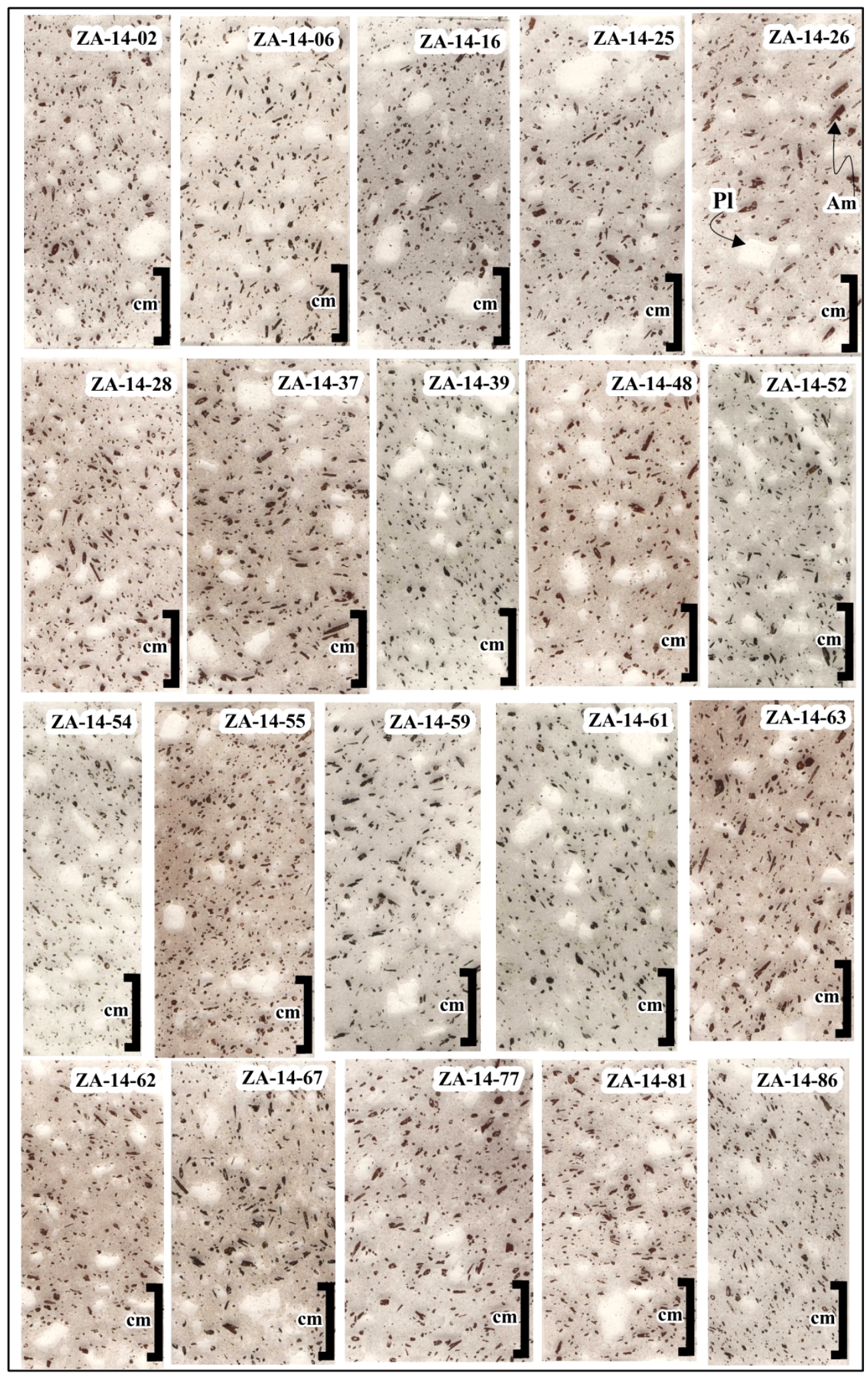

Fig. 3 Digitized images of thin sections of 20 dacite samples from the Zanbil volcanic rocks.

theoretical basis for CSD studies is taken from Marsh (1988) and Cashman and Ferry (1988).

For this study, 20 thin sections of Zanbil dacites possessing phases and textures of interest for CSD studies were selected. An image of each thin section was generated by projection onto a wall and photographing the magnified image (Fig. 3). The outlines of plagioclase and amphibole crystals were traced digitally. Grain sizes were (maximum lengths and widths) were calculated using 'Digimizer'. We used Digimizer software for image processing by binarization of image and threshold determination for 
Table 1 Length distributions in amphibole and plagioclase crystals in the Zanbil adakitic dacites. The number of crystals counted by the CSD corrections program for various size intervals in each sample is listed. The data were used to construct the CSD plots.

\begin{tabular}{lrrrrrrrrr}
\hline & \multicolumn{10}{c}{ Amphibole/ Size Intervals (cm) } \\
\hline Sample No. & $\mathbf{0 . 0 1 0 0 -}$ & $\mathbf{0 . 0 1 5 8 -}$ & $\mathbf{0 . 0 2 5 1 -}$ & $\mathbf{0 . 0 3 9 8 -}$ & $\mathbf{0 . 0 6 3 1 -}$ & $\mathbf{0 . 1 0 0 -}$ & $\mathbf{0 . 1 5 8 -}$ & $\mathbf{0 . 2 5 1 -}$ & $\mathbf{0 . 3 9 8 -}$ \\
& $\mathbf{0 . 0 1 5 8}$ & $\mathbf{0 . 0 2 5 1}$ & $\mathbf{0 . 0 3 9 8}$ & $\mathbf{0 . 0 6 3 1}$ & $\mathbf{0 . 1 0 0}$ & $\mathbf{0 . 1 5 8}$ & $\mathbf{0 . 2 5 1}$ & $\mathbf{0 . 3 9 8}$ & $\mathbf{0 . 6 3 1}$ \\
\cline { 2 - 5 } & 18 & 237 & 254 & 112 & 69 & 34 & 15 & 9 & 1 \\
ZA-14-06 & 45 & 346 & 154 & 54 & 34 & 29 & 20 & 3 & 1 \\
ZA-14-16 & 102 & 456 & 501 & 411 & 105 & 98 & 30 & 0 & 0 \\
ZA-14-25 & 83 & 334 & 402 & 128 & 46 & 20 & 11 & 2 & 1 \\
ZA-14-26 & 195 & 254 & 280 & 102 & 67 & 34 & 3 & 0 & 0 \\
ZA-14-28 & 256 & 578 & 405 & 338 & 115 & 50 & 12 & 1 & 0 \\
ZA-14-37 & 35 & 723 & 488 & 415 & 92 & 78 & 15 & 4 & 0 \\
ZA-14-39 & 67 & 634 & 403 & 376 & 136 & 47 & 23 & 13 & 0 \\
ZA-14-48 & 104 & 651 & 276 & 235 & 57 & 92 & 18 & 5 & 0 \\
ZA-14-52 & 154 & 765 & 543 & 518 & 43 & 30 & 16 & 3 & 0 \\
ZA-14-54 & 76 & 589 & 380 & 318 & 89 & 50 & 19 & 6 & 0 \\
ZA-14-55 & 54 & 376 & 267 & 207 & 67 & 39 & 20 & 1 & 0 \\
ZA-14-59 & 98 & 223 & 206 & 275 & 98 & 74 & 18 & 12 & 1 \\
ZA-14-61 & 74 & 534 & 482 & 344 & 125 & 67 & 21 & 15 & 0 \\
ZA-14-63 & 85 & 446 & 405 & 310 & 86 & 19 & 17 & 9 & 0 \\
ZA-14-62 & 64 & 398 & 198 & 234 & 99 & 74 & 28 & 1 & 0 \\
ZA-14-67 & 187 & 429 & 365 & 256 & 98 & 90 & 9 & 5 & 0 \\
ZA-14-77 & 145 & 578 & 516 & 209 & 87 & 43 & 31 & 7 & 0 \\
ZA-14-81 & 78 & 387 & 340 & 384 & 65 & 37 & 26 & 4 & 1 \\
ZA-14-86 & 65 & 499 & 453 & 235 & 147 & 54 & 19 & 11 & 0 \\
av. & 99 & 472 & 366 & 273 & 86 & 53 & 19 & 6 & $<1$ \\
\hline
\end{tabular}

each mineral. Subsequently, the data were transferred to the CSD Corrections program (v. 1.4.0.2) (a standard spread sheet) after Higgins (2000), for perform the $2 \mathrm{D}$ to $3 \mathrm{D}$ conversion and the calculation of CSD plots for each mineral type (Fig. 4 and Fig. 8). Both length and width data were collected but only length data are presented here. The crystal habit according to the short, intermediate and long axes for amphibole was 1:1.5:3 (Modjarrad, 2015a) and for plagioclase, was 1:1.5:1.5 (Higgins, 2002), based on manual measurements of the images, which are similar to data for prismatic crystals used by Morgan and Jerram (2006). The roundness factor used in the program was 0.6 for amphiboles and 0.5 for plagioclases, which is the average average given by the image processing software (Digimizer) for crystal roundness. The crystal fabric was considered to be isotropic.

The Y-axis of CSD plots denotes the natural logarithm (Ln) of population density $\left(\mathrm{cm}^{-4}\right)$, and the $\mathrm{X}$-axis denotes the Length bins (per $\mathrm{cm}$ ). The slope of the regression line (b) provides information on the rate of mineral growth and the average time required for crystallization or the residence time in the magma chamber $(-1 / \mathrm{Gt})$. The interpretation of the CSD slope as $-1 / \mathrm{Gt}$ relates to crystallization in model open systems under some assumptions (e.g. Marsh, 1988; Lasaga, 1998). The zero intercept equals the population density (Daniel and Spear, 1999; Higgins,
$2000)$ and the ratio of nucleation rate to growth rate $(\mathrm{J} / \mathrm{G})$.

\section{RESULTS}

Here we present the CSD results for amphibole and plagioclase of Zanbil adakitic dacites (20 thin sections). In each thin section, the number of crystals of each phase was determined by size category. Crystal length (L) was chosen as the greatest dimension, and the data were compiled following the statistical method proposed by Higgins (2000). The total number of grains $(\mathrm{Nt})$ was calculated by summing up the number of crystals in all size categories. The CSD patterns for plagioclase show a flat segment between fine and coarse grains.

A convex-up curve of CSD can be a result of many different processes, such as accumulation of fines, and magma mixing. If the original linear CSD plot is deflected downwards then fractionation or loss of larger crystals might have occurred (Marsh, 1988).

\section{AMPHIBOLE}

The complete statistical dataset for fine- and coarse-grained amphibole crystals (all without any reaction rims) is presented in Figure 4 and Table 1. In Figure 4, each sample is represented by a CSD pattern defined by its slopes $(S)$ and intercepts $\left(n^{\circ}\right)$ for a total number of crystals per volume unit. For amphiboles the pattern is non-linear as a result of the combination 


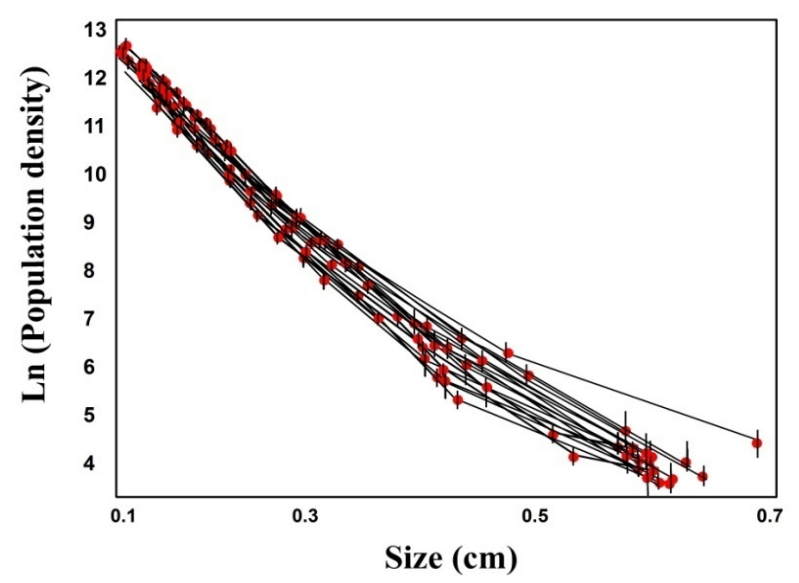

Fig. 3 Digitized images of thin sections of 20 dacite samples from the Zanbil volcanic rocks. These images were used to calculate the morphometrical parameters using the Digimizer software. Size of thin sections $\sim 4 \times 2 \mathrm{~cm}$.

of two segments, suggesting that they formed under conditions of non-steady state growth and nucleation. The slope of each segment is proportional to the deviation of the population around the mean crystal size (Lm). The intercept of each part is the extrapolated number of grains of a population when the crystal size (L) tends to zero. Each line corresponds to a given sample distribution of a phase within a certain size range. Ten size bins were determined in which the number of nuclei diminishes with size (Table 1). A common feature of these CSDs is a concave up, lognormal shape, contrasting the expected linear pattern. All 15 samples have similar, two segmental patterns, intercept values and slopes.

\section{PLAGIOCLASE}

Plagioclase occurs both as phenocrysts and in matrix (Table 1, continued.). The CSDs are strongly curved, concave up (Fig. 5). All CSDs are coincident

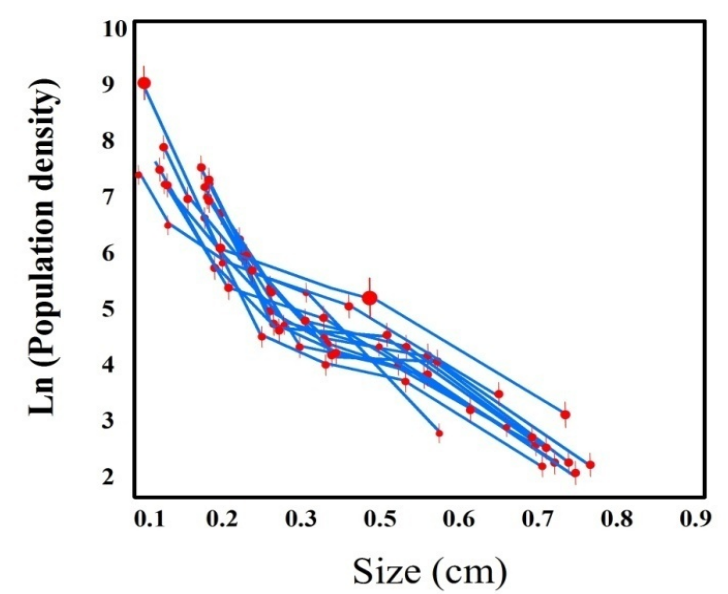

Fig. 4 CSD plots for amphibole crystals from the Zanbil adakitic dacites.

and there does not appear to be any progression or change in CSD from dacite to trachy-andesitic compositions.

\section{DISCUSSION}

\section{FORM OF CSD PATTERNS: MAGMA MIXING OR TEXTURAL COARSENING?}

There are no great difference between CSDs for amphibole and plagioclase. Therefore all interpretations are correct for the two mineral groups. Just for plagioclase, there is a flattened part at the boundary of fine and coarse grains and slightly concave downward at the coarse grains part. Generally the CSD plots for the amphibole and plagioclase crystals are not linear but curve concavely upwards (Figs. 4 and 5). Hence, a simple model based on a single population of crystals cannot be successfully applied. If we assume that the growth rate was constant with size in each case of the studied samples, it appears that more than one crystallization event is required to explain their growth histories. Such curved CSDs have been reported from other volcanic rocks (e.g. Maaloe et al. 1989; Armienti et

Table 1 Continued.

\begin{tabular}{|c|c|c|c|c|c|c|c|c|}
\hline \multicolumn{9}{|c|}{ Plagioclase/ Size Intervals (cm) } \\
\hline Sample No. & $\begin{array}{c}0.0398- \\
0.0631 \\
\end{array}$ & $\begin{array}{c}0.0631- \\
0.100 \\
\end{array}$ & $\begin{array}{c}0.100- \\
0.158 \\
\end{array}$ & $\begin{array}{c}0.158- \\
0.251\end{array}$ & $\begin{array}{c}0.251- \\
0.398\end{array}$ & $\begin{array}{l}0.398- \\
0.631\end{array}$ & $\begin{array}{c}0.631- \\
1\end{array}$ & $\begin{array}{c}1- \\
1.58\end{array}$ \\
\hline ZA-14-02 & 5 & 14 & 13 & 6 & 7 & 7 & 2 & 1 \\
\hline ZA-14-06 & 4 & 11 & 15 & 9 & 4 & 1 & 1 & 0 \\
\hline ZA-14-16 & 7 & 19 & 21 & 11 & 3 & 4 & 2 & 1 \\
\hline ZA-14-26 & 5 & 15 & 14 & 6 & 2 & 3 & 0 & 0 \\
\hline ZA-14-37 & 7 & 21 & 16 & 5 & 4 & 5 & 1 & 0 \\
\hline ZA-14-48 & 6 & 16 & 12 & 8 & 2 & 3 & 2 & 0 \\
\hline ZA-14-52 & 11 & 14 & 9 & 3 & 6 & 4 & 1 & 0 \\
\hline ZA-14-54 & 3 & 18 & 12 & 5 & 5 & 2 & 3 & 0 \\
\hline ZA-14-55 & 5 & 12 & 15 & 7 & 1 & 6 & 2 & 0 \\
\hline ZA-14-63 & 9 & 17 & 17 & 11 & 3 & 5 & 0 & 1 \\
\hline ZA-14-62 & 7 & 34 & 21 & 9 & 7 & 3 & 1 & 2 \\
\hline ZA-14-77 & 6 & 11 & 4 & 4 & 4 & 4 & 1 & 0 \\
\hline ZA-14-86 & 8 & 15 & 4 & 5 & 2 & 4 & 2 & 0 \\
\hline av. & 6 & 17 & 13 & 7 & 4 & 4 & 1 & $<1$ \\
\hline
\end{tabular}



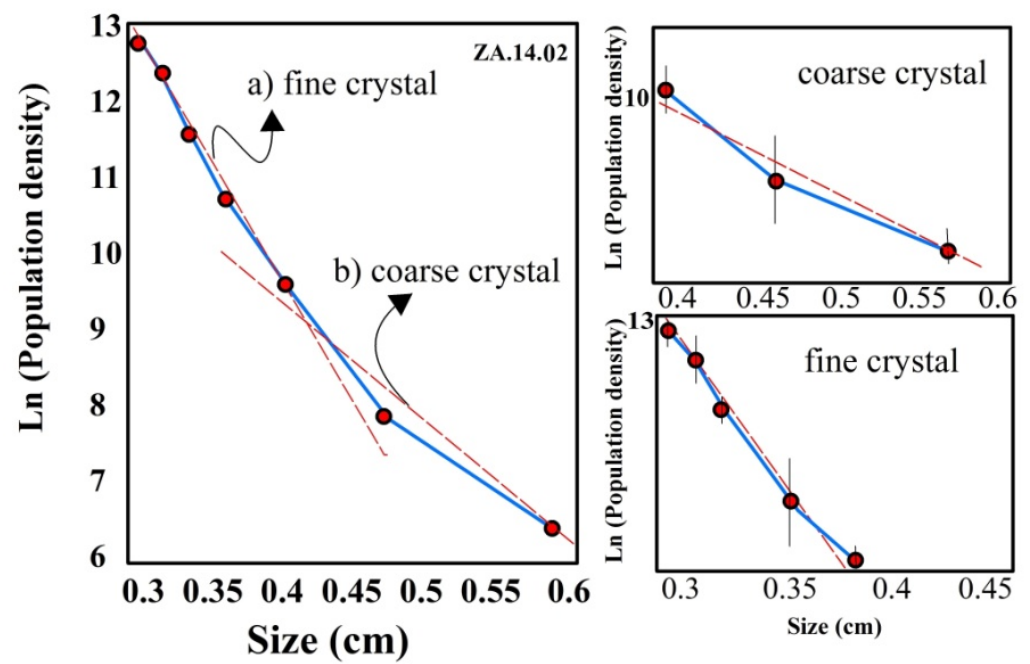

Fig. 6 CSD plots for plagioclase crystals from the Zanbil adakitic dacites.
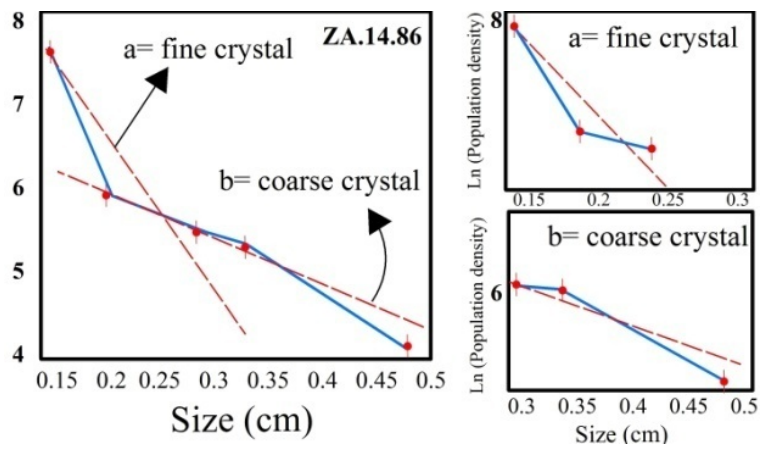

Fig. 7 Fitting of a mixture of two magmas with linear CSDs to the observed CSD of sample ZA-14-02 as a representative sample for amphiboles. The two linear segments for the fine and coarse grains are shown by dashed lines.

al., 1994; Modjarrad, 2015a) and several different explanations for curved CSDs have been proposed (Marsh, 1988):

Accumulation of crystals and dependence of growth rate on crystal size, with constant growth rate is independent of crystal size (Cashman and Marsh, 1988).

Fines destruction, during which small crystals are desorbed and their nutrients fed to larger crystals. This process (coarsening) produces curved CSDs with curvatures that are opposite to those obtained in the present study. Therefore, this mechanism is considered as not relevant for the Zanbil amphiboles but it is slightly true for plagioclase coarse grains (Fig. 5).

Abrupt changes in cooling rate: slow cooling at depth followed by more rapid cooling in the conduit (Armienti et al., 1994). Cashman (1993) proposed that curved CSDs can be produced at a constant cooling rate if there is a change in the nature of the precipitating phases (megacryst and microlite).
The final theory, considered by Higgins (1996), is the mixing of magmas with contrasting CSDs which yields a CSD with a steep slope for small sizes and a gentler slope for larger sizes. Such a mixing process is shown in Figures 6 and 7. Due to the logarithmic scale of the population density axis summation of the two linear CSDs gives a curved CSD (Higgins, 1996). Clearly, the slope of the original CSD of each magma can be recovered from the linear segments (Figs. 5 and 6), but should be corrected for the dilution effect by the other magma. The phenocryst population can be identified as crystals inherited from one of the parental magmas, but fine grains were inherited from one of the parent magmas or must have formed after the mixing event. This problem has not been solved yet. The population distributions of the Zanbil adakitic dacites were modeled by mixing together two populations of crystals with linear CSDs, termed fine grains and phenocrysts, for both amphibole and plagioclase. The slope and intercept parameters for each population in each sample were varied until the sum of the differences between the model and the actual data was minimized (Table 2, Figs. 6 and 7). Geochemical evidence for magma contamination such as depletion in HREE, high field-strength elements and $\mathrm{Ti}, \mathrm{Nb}$ and $\mathrm{Ta}$ beside to enrichment in large ion lithophile elements (Modjarrad, 2015a) also supports the CSD results. As shown in Table 2, the amphibole volume fractions in the samples are $2-5 \%$ and the data show that approximately $40 \%$ of it is phenocrysts.

With the injection of a second magma into the chamber (Devine et al., 1998a), or perhaps by convective mixing of magma already warmed by newly injected magma (Couch et al., 2001), the mixing of old coarse grains and fine new grains occurred.

It is reasonable to ask if the slope and intercept parameters of the two crystal populations are in accordance with each other and with CSDs of other rocks, even if the intercepts have been slightly 
Table 2 Amphibole and plagioclase CSD data from the Zanbil adakitic dacites. Different growth rates reflect the range of growth rates determined for silicate systems from experiment and numerical modeling (Swanson, 1977; Lasaga, 1982; Spohn et al., 1988; Cashman, 1993).

\begin{tabular}{|c|c|c|c|c|c|c|c|c|c|c|}
\hline Amphibole & & & & $\begin{array}{c}\text { Fine } \\
\text { crystals }\end{array}$ & & & & $\begin{array}{l}\text { Coarse } \\
\text { crystals }\end{array}$ & & \\
\hline $\begin{array}{c}\text { Sample } \\
\text { No. }\end{array}$ & $\begin{array}{c}\text { All } \\
\text { Am. } \\
\text { covered } \\
\text { area } \\
\left(\mathrm{cm}^{2}\right)\end{array}$ & $\begin{array}{l}\text { Covered } \\
\text { area } \%\end{array}$ & $\begin{array}{l}\text { Slope } \\
(-1 / \mathrm{Gt})\end{array}$ & $\begin{array}{l}\text { Intercept } \\
\text { value } \\
\left(\mathrm{Ln} \mathrm{n}_{0}\right) \\
\mathrm{mm}^{-4}\end{array}$ & $\begin{array}{c}\text { Log } \\
\text { Gt }\end{array}$ & $\begin{array}{c}\text { Residence } \\
\text { Time } \\
\text { (year) } \\
\text { Based on } \\
\mathrm{G}=10^{-10} \\
\mathrm{~cm} / \mathrm{s}\end{array}$ & $\begin{array}{l}\text { Slope } \\
(-1 / \mathrm{Gt})\end{array}$ & $\begin{array}{l}\text { Intercept } \\
\text { value } \\
\left(\mathrm{Ln} \mathrm{n}_{0}\right) \\
\mathrm{mm}^{-4}\end{array}$ & $\begin{array}{l}\log \\
(\mathrm{Gt})\end{array}$ & $\begin{array}{c}\text { Residence } \\
\text { Time } \\
\text { (year) } \\
\text { Based on } \\
\mathrm{G}=10^{-10} \\
\mathrm{~cm} / \mathrm{s}\end{array}$ \\
\hline ZA-14-02 & 0.976 & 7.34 & -17.4 & 13.03 & -1.24 & 16.11 & -10.34 & 7.05 & -1.01 & 31.19 \\
\hline ZA-14-06 & 0.701 & 6.44 & -15.4 & 12.85 & -1.18 & 20.61 & -9.23 & 9.87 & -0.96 & 34.94 \\
\hline ZA-14-16 & 0.768 & 6.87 & -16.6 & 12.08 & -1.22 & 19.32 & -11.04 & 9.15 & -1.04 & 29.21 \\
\hline ZA-14-25 & 0.956 & 7.16 & -12.7 & 11.68 & -1.10 & 22.53 & -8.26 & 9.11 & -0.93 & 39.05 \\
\hline ZA-14-26 & 0.354 & 2.96 & -17.9 & 12.85 & -1.25 & 16.16 & -14.65 & 6.34 & -1.16 & 22.01 \\
\hline ZA-14-28 & 0.567 & 4.71 & -15.0 & 12.47 & -1.17 & 19.63 & -13.5 & 8.12 & -1.13 & 23.89 \\
\hline ZA-14-37 & 0.173 & 1.32 & -14.5 & 12.82 & -1.16 & 19.33 & -9.01 & 11.32 & -0.95 & 38.80 \\
\hline ZA-14-39 & 0.693 & 5.09 & -17.5 & 12.67 & -1.24 & 16.41 & -12.59 & 8.67 & -1.10 & 25.62 \\
\hline ZA-14-48 & 0.645 & 4.87 & -13.0 & 13.02 & -1.28 & 24.76 & -11.21 & 10.13 & -1.04 & 28.77 \\
\hline ZA-14-52 & 0.348 & 2.75 & -14.7 & 12.27 & -1.16 & 21.29 & -10.43 & 8.32 & -0.92 & 30.92 \\
\hline ZA-14-54 & 0.645 & 4.87 & -19.3 & 12.66 & -1.28 & 16.07 & -11.28 & 10.76 & -1.03 & 28.59 \\
\hline ZA-14-55 & 0.776 & 6.94 & -14.5 & 11.89 & -1.16 & 22.61 & -12.49 & 6.94 & -1.09 & 25.82 \\
\hline ZA-14-59 & 0.357 & 2.95 & -13.9 & 11.67 & -1.14 & 23.01 & -9.34 & 7.84 & -0.97 & 34.53 \\
\hline ZA-14-61 & 0.546 & 4.83 & -11.6 & 10.93 & -1.06 & 27.81 & -9.05 & 5.65 & -0.95 & 35.64 \\
\hline ZA-14-63 & 0.234 & 2.04 & -14.6 & 11.39 & -1.16 & 22.03 & -10.82 & 9.87 & -1.03 & 29.81 \\
\hline ZA-14-62 & 0.304 & 2.41 & -17.5 & 12.85 & -1.24 & 18.4 & -10.78 & 8.17 & -1.02 & 29.99 \\
\hline ZA-14-67 & 0.611 & 4.19 & -12.7 & 11.78 & -1.09 & 25.37 & -9.03 & 10.03 & -0.94 & 35.72 \\
\hline ZA-14-77 & 0.7 & 6.08 & -11.4 & 12.96 & -1.05 & 28.26 & -8.37 & 8.23 & -0.93 & 38.54 \\
\hline ZA-14-81 & 0.445 & 3.78 & -17.0 & 12.99 & -1.23 & 18.93 & -14.83 & 7.34 & -1.17 & 21.75 \\
\hline ZA-14-86 & 0.376 & 3.11 & -17.5 & 12.93 & -1.24 & 18.44 & -15.34 & 8.97 & -1.18 & 21.02 \\
\hline
\end{tabular}
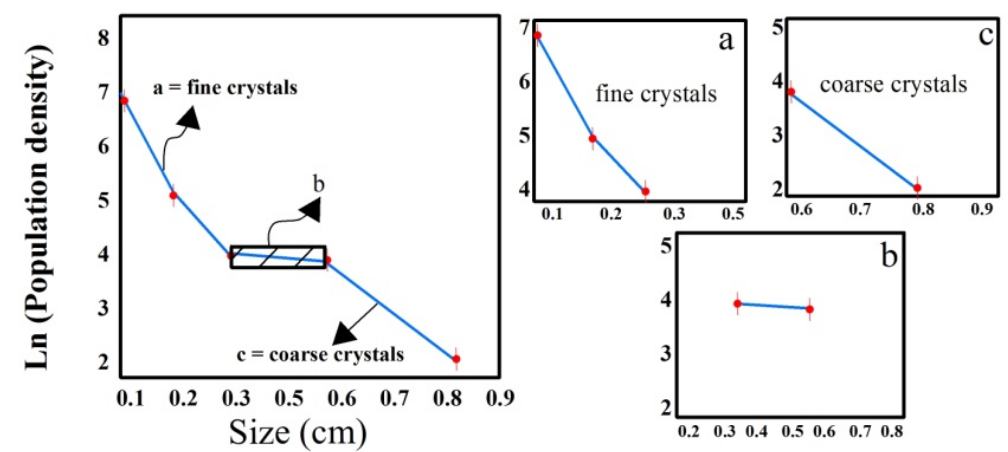

Fig. 8 Three segmental CSDs for some plagioclases such as: ZA-14-62. A middle part (b) is shown at the end of the first part (fine grains, (a) and before the coarse episode (c) with lower slope at the CSD pattern. It is as a result of textural coarsening before second magma intruded at the chamber.

displaced to lower values by dilution effects (Higgins, 1996). Both phenocryst and fine grain populations have linear distributions on a plot of $\mathrm{Ln} \mathrm{n}$ (nucleation density), that is the intercept of the CSD vs Log (Gt) that is $\log (-1 /$ slope) (Figs. 6 and 7$)$. These distributions are linear and parallel with each other and with plagioclase and amphibole crystals in a variety of other volcanic rocks. This correlation suggests that the CSDs found here are indeed meaningful. Furthermore, residence times for amphibole nuclei and phenocrysts in Zanbil adakitic dacites are twice as long compared to those of amphiboles in the Mutro dyke (Nkono et al., 2006).

Higgins and Roberge (2003) have shown that the Communicating Neighbors Model textural coarsening could also be a response to amphibole oikocrysts existence. In this model, large crystals may originally formed as many small crystals, which followed by a period of textural coarsening that reduced the crystal number density and enlarged the largest crystal by solution of the smallest crystals (Voorhees, 1992). Such explanation could be used for the Zanbil 

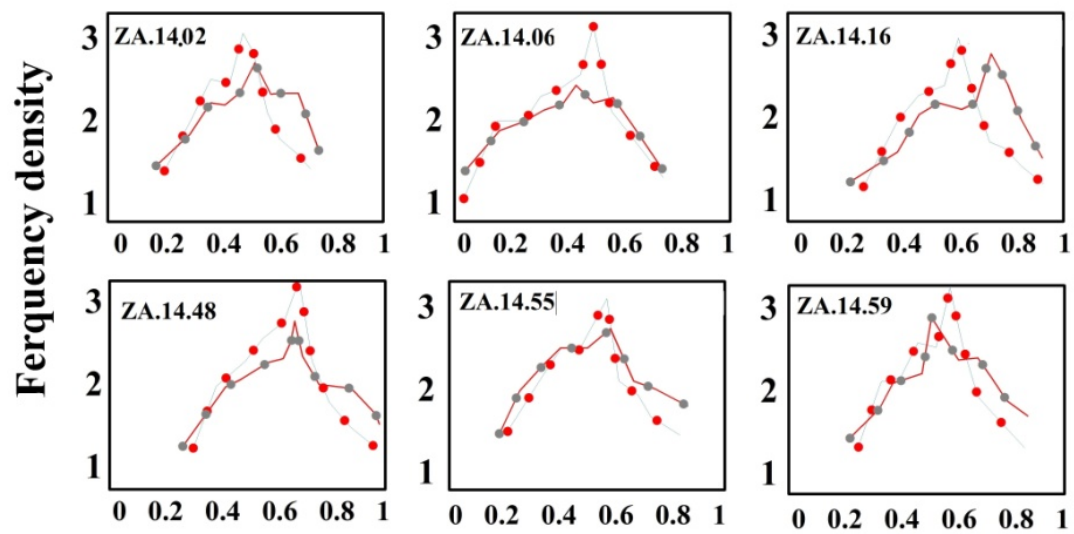

\section{intersection Widtht / intersection Length}

Fig. 9 Intersection of width / length for the Zanbil adakitic dacites amphiboles is approximately 0.6. Separate curves are presented for measured and model distribution. The frequency is the number of crystals in each interval divided by the total number of crystals and the interval width.
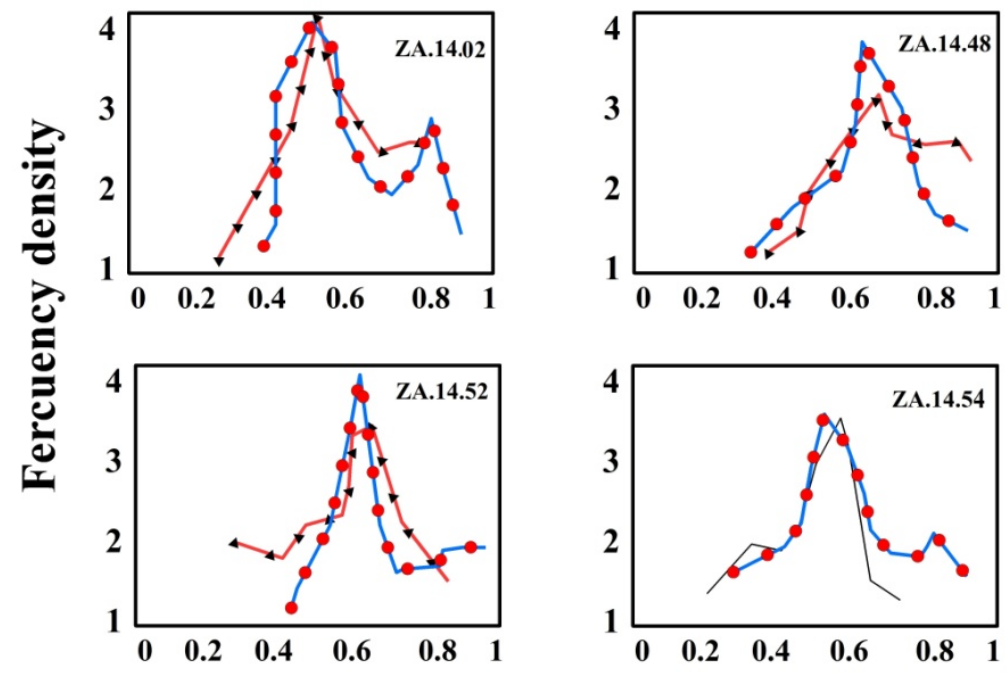

\section{Intersection Width / Intersection Length}

Fig. 10 Intersection width / length for the Zanbil adakitic dacites plagioclases is approximately 0.6, similar to amphiboles. Separate curves are presented for measured and model distribution.

amphibole phenocrysts formation and next to the mixing assumption can be useful for understanding the crystallization history of Zanbil volcano. Also the flattened part of the plagioclase CSDs are shown. According to Higgins and Roberg (2003) solution and textural coarsening after nucleation and growth flatten the CSD (Fig. 8).

The segments for fine and coarse grains each show an approximately log-linear relationship between population density and crystal size, suggesting they formed under conditions of steady state growth and nucleation.

A period of textural coarsening reduced the crystal number density and enlarged the largest crystals (particularly plagioclase) by solution of the smallest crystals (Voorhees, 1992) at this study. At the last episode the magma temperature decreased and cause to crystallization of small sized plagioclases which is reflect as higher values of intercept at the pattern (Yu et al., 2012).

\section{RESIDENCE TIME AND CRYSTAL HABIT}

If the growth rate is known, crystallization times can be calculated using CSD curves. Cashman (1993) has shown that there is a strong correlation between cooling rate (or its inverse, crystallization time) and plagioclase growth rate. For crystallization times constrained by conductive cooling models, the growth rates calculated by Spillar and Dolejz (2013) for representative CSDs (for conditions similar to lava lakes) are of the order of $10^{-11} \mathrm{~cm} \mathrm{~s}^{-1}$, which is in a good agreement with in situ observations of Hawaiian lava lakes. Calculated growth rates are inversely proportional to the magma body size (and slope of the CSD) and increase from the chamber interior to the margins. Growth rates of $10^{-10}$ to $10^{-11} \mathrm{~cm} / \mathrm{s}$ have been 


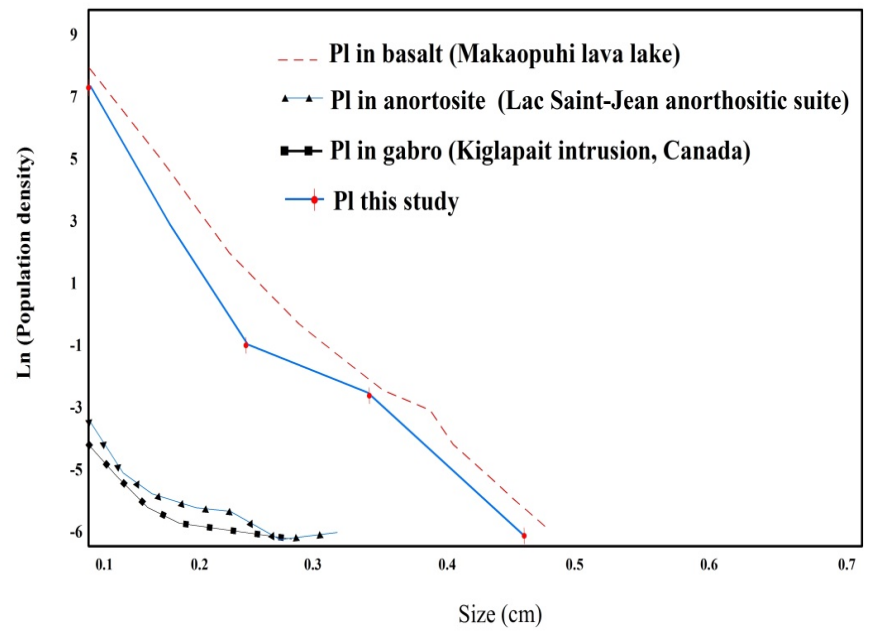

Fig. 11 Comparison of the Zanbil dacites, plagioclase CSD pattern with other well studied extrusive and intrusive igneous rocks plagioclase CSDs. The slope and intercept values for volcanic plagioclases are similar, independent from acidic or basic affinities. But as showed at the graph, the intrusive crystals have another characteristic, because of the larger time range, which is available for each crystal.

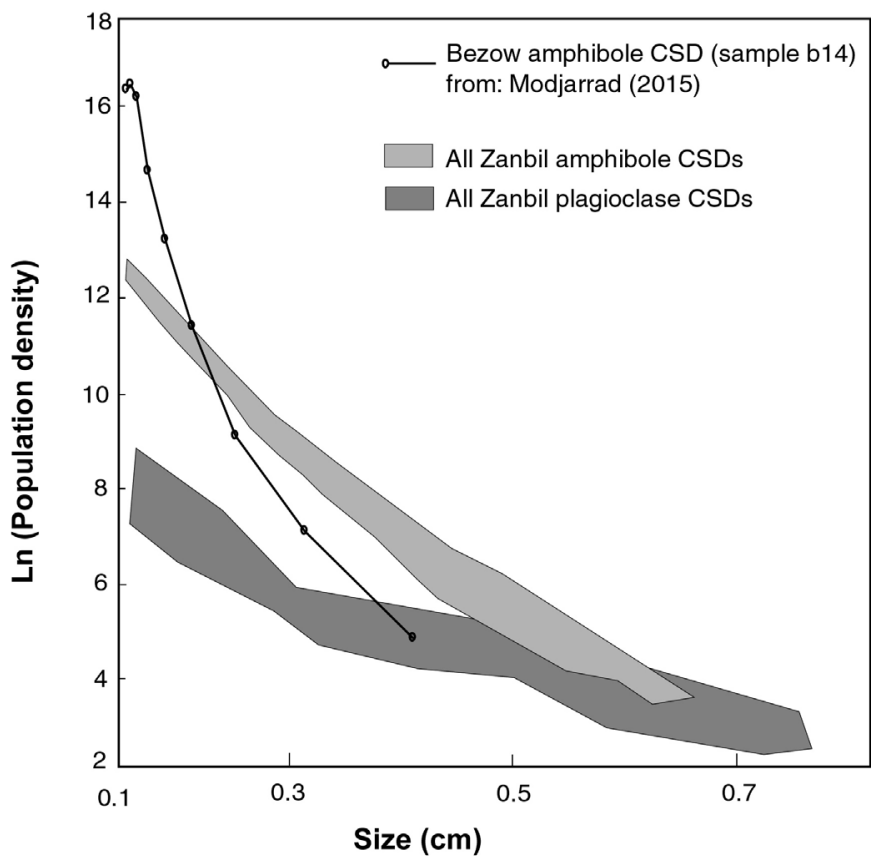

Fig. 12 All CSDs of amphibole and plagioclases from the Zanbil dacites. The illustration shows that amphiboles had further nuclei than plagioclase, but plagioclases were coarsened than amphiboles. The textural coarsening segment (flattened part) at the plagioclase CSDs is noticeable. As a comparison the Bezow dacite amphiboles is plotted, too. The magma mixing evidences at the Bezow amphiboles CSD is better than Zanbil.

used in literature for silicate minerals such as plagioclase and amphibole or pyroxene at the volcanic rocks (show the introduction part references). A cooling (residence) time of 15-20 years for fine grains and 30-38 years for phenocrysts is calculated for Zanbil phenocrysts (Table 2) based on a growth rate of $10^{-10} \mathrm{~cm} / \mathrm{s}$, evidently the time would be 150 200 years for fine grains and 300-380 years for phenocrysts if the growth rate was $10^{-11} \mathrm{~cm} / \mathrm{s}$. Not taking into account real growth rate and actual radiometric ages, residence times in the magma chamber of the amphibole phenocrysts were twice as long as those of the fine amphibole grains. It is important that we realize that some of the phenocrysts may have formed in the host magma by coarsening. This was probably enabled by cycling of the temperature of the magma around the amphibole liquidus temperature in response to magma injections and subsequent magmatic overturns. It is possible that the fine grains grew after mixing of two magmas. New magma with few or no crystals entered the chamber containing the megacryst-bearing magma and eruption followed 15-20 years later. If the compositions of the fine grains and the phenocrysts 


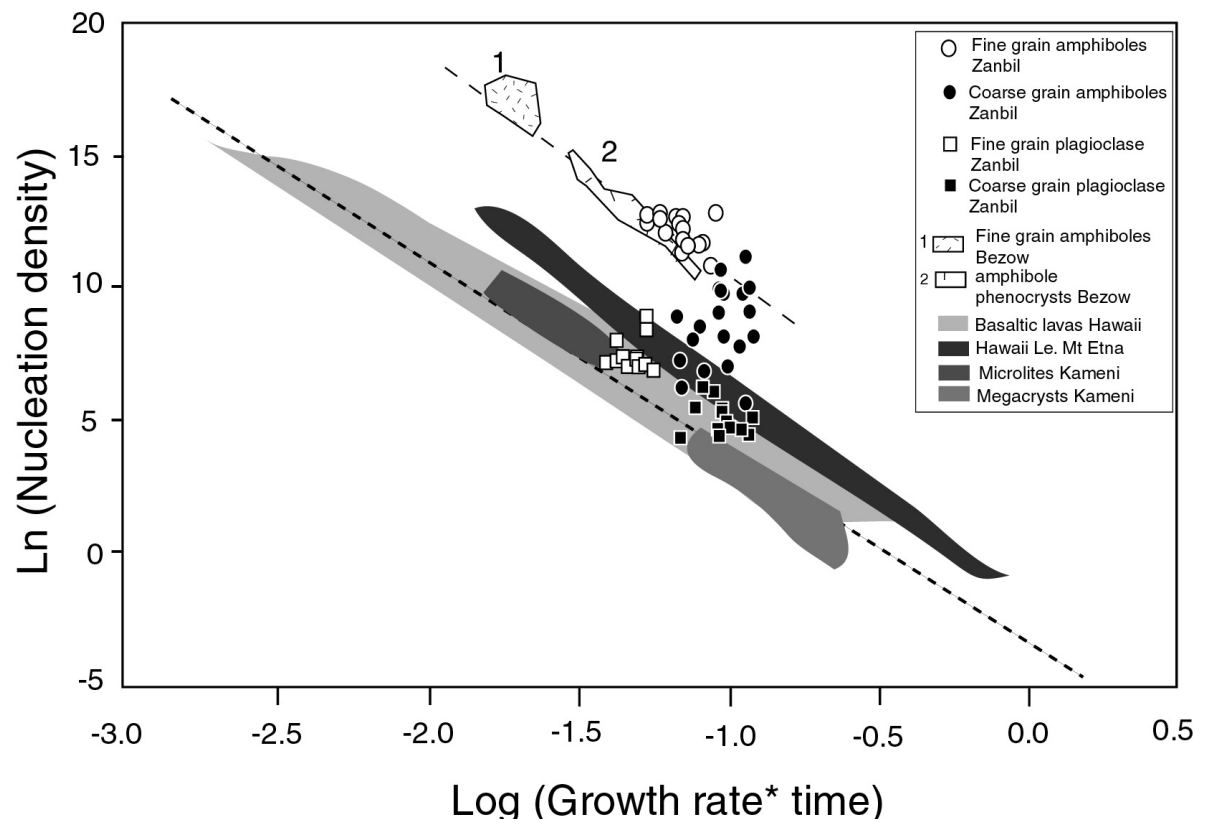

Fig. 13 Compilation of Ln (nucleation density) vs. Log (Gt) for amphibole and plagioclase crystals from several rock types. The dashed line is an estimate of the correlation of the data. Plagioclase: Kameni microlites and megacrysts from Higgins (1996), Hawaii from Cashman (1990), Mt. Etna from Armienti et al. (1994) and Bezow from Modjarrad (2015a).

are similar, then the above assumption is correct. The phenocrysts have a longer (30-38 years) residence time than the fine grains (Table 2).

Crystal habits are controlled by the physicalchemical conditions of crystallization (Sunagawa, 1987). Higgins (1994) has shown that it is possible to estimate the crystal habit from the width/length ratio distributions. Intersection of width / length ratio distributions are similar for all 20 Zanbil samples (Figs. 9 and 10) resulting in similar patterns with a peak of around 0.6 , for both minerals, comparable to the model pattern of the CSD corrections program which has a peak at 0.6 (Figs. 9 and 10). As stated above, the used parameters for amphibole crystal habit in the short, intermediate and long axes were 1:1.5:3 and 1:1.5:1.5 for plagioclases.

\section{COMPARISON WITH OTHER SIMILAR WORKS}

We have compared the CSD pattern of the plagioclase of Zanbil dacites with other well studied extrusive and intrusive igneous rocks plagioclase CSDs (Fig. 11). The slope and intercept values for volcanic plagioclases are similar, independent of acidic or basic affinities. But as shown in the graph, the intrusive crystals have another characteristic, because of the larger time range available for each crystal. All CSDs of amphibole and plagioclases from Zanbil dacites are plotted on the one graph (Fig. 12). The illustration shows that the amphiboles had further nuclei than plagioclase, but plagioclases were coarsened than amphiboles. The textural coarsening segment (flattened part) at the plagioclase CSDs is noticeable. As a comparison, the Bezow dacites amphiboles are plotted, too. The magma mixing evidence is better than Zanbil, at the Bezow (two distinct parts with different slopes and intercept values, Fig. 12). The results show that the number of amphibole nucleus at the Bezow are more than in the Zanbil dacites, but it is in correlation with the Bezow at the Ln (N) vs. Log Gt diagram (Fig. 13). The Zanbil plagioclase parameters lie on the other plagioclase trends at the same well studied volcanic rocks (Fig. 13).

\section{CONCLUSIONS}

Quantitative textural analysis of a series of samples from the Zanbil adakitic dacites indicates that their textures reflect two separate events during magma evolution and that the adakitic dacites formed by refilling and partial emptying of a magma chamber. A dacitic magma containing few crystals was emplaced into a shallow magma chamber, probably at a depth of a few kilometers, after 30-38 years of crystallization in a deep chamber. The newly added magma mixed with the existing magma, and the mixed magma (made up of both old and new components) remained in the chamber for 15-20 years. Higgins (1996) offered such a model for the first time and suggested that it may be generalized to other volcanoes. As the magma ascended into the crust, heat is withdrawn at a constant rate, resulting in nucleation and growth of phases, particularly plagioclase. The textural coarsening which occurred on plagioclase grains is documented at the middle flattened part of the curves.

Refilling occurred repeatedly, but rarely the chamber completely emptied. In comparison, the residence time of the phenocryst-bearing Zanbil dacite 
magma in the deeper chamber was longer than the second, pheno- or megacryst-bearing magma. Possibly, a significant distance existed between the shallow and deep chambers. The amphibole phenocrysts resided twice as long as the fine-grained amphiboles in the Zanbil volcanic rocks. We compared the above CSDs with the Bezow dacites patterns to determine if the trends are similar. The results show that the number of amphibole nuclei at the Bezow is more than in the Zanbil dacites, but it is in correlation with the Bezow at the $\mathrm{Ln}(\mathrm{N})$ vs. Log Gt diagram. The comparison of plagioclase factors with the other areas show that our results are meaningful and as a rule, the number of plagioclase nuclei is less than for amphibole in the dacitic rocks.

\section{ACKNOWLEDGMENTS}

This work was supported financially by the Research Bureau of Urmia University. The authors would like to express their gratitude to the authorities of this bureau.

\section{REFERENCES}

Aghanabati, A.: 2004, Geology of Iran. Geological Survey of Iran; Tehran, $582 \mathrm{pp}$, (in Persian).

Armienti, P., Pareschi, M.T., Innocenti, F. and Pompilio, M.: 1994, Effects of magma storage and ascent on the kinetics of crystal growth. Contributions to Mineralogy and Petrology, 115, 402-414. DOI: $10.1007 / \mathrm{BF} 00320974$

Cashman, K.V. and Marsh, B.D.: 1988, CSD rocks and the kinetics and dynamics of crystallization, II Makaopuhi lava lake. Contributions to Mineralogy and Petrology, 99, 292-305. DOI: 10.1007/BF00375363

Cashman, K.V.: 1993, Relationship between plagioclase crystallization and cooling rate in basaltic melts. Contributions to Mineralogy and Petrology, 113, 126142. DOI: $10.1007 / \mathrm{BF} 00320836$

Cashman, K.V.: 1990, Textural constraints on the kinetics of crystallization of igneous rocks. Reviews in Mineralogy and Geochemistry, 24, 259-314.

Cashman, K.V.: 1992, Groundmass crystallization of Mount St. Helens adakitic dacites, 1980-1986: a tool for interpreting shallow magmatic processes. Contributions to Mineralogy and Petrology, 109, 431449. DOI: 10.1007/BF00306547

Castro, J.M. Cashman, K.V. and Manga, M.: 2003, A technique for measuring 3D CSD of prismatic microlites in obsidian. American Mineralogist, 88, 1230-1240. DOI: 10.2138/am-2003-8-906

Cooper, K.M. and Reid, M.R.: 2003, Re-examination of crystal ages in recent Mount St. Helens lavas. Earth and Planetary Science Letters, 213, 149-167.

DOI: $10.1016 / \mathrm{S} 0012-821 \mathrm{X}(03) 00262-0$

Couch, S., Sparks, R.S.J. and Carrol, M.R.: 2001, Mineral disequilibrium in lavas explained by convective selfmixing in open magma chambers. Nature, $411,1037-$ 1039. DOI: $10.1038 / 35082540$

Daniel, C.G. and Spear, F.S.: 1999, The clustered nucleation and growth of garnet in regional metamorphic rocks from north-west Connecticut, USA. Journal of Metamorphic Geology, 17, 503-520. DOI: $10.1046 / j .1525-1314.1999 .00200 . x$
Hammer, J.E., Cashman, K.V., Hoblitt, R.P. and Newman, S.: 1999, Degassing and microlite crystallization during pre-climactic eventsof Mt. Pinatubo, Philippines. Bulletin of Volcanology, 60, 355-380. DOI: $10.1007 / \mathrm{s} 004450050238$

Higgins, M.D. and Roberge, J.: 2003, Crystal size distribution of plagioclase and amphibole from Soufriere Hills volcano, Montserrat: evidence for dynamic crystallization, textural coarsening cycles. Journal of Petrology, 44 (8), 1401-1411. DOI: $10.1093 /$ petrology/44.8.1401

Higgins, M.D.: 1994, Determination of crystal morphology and size from bulk measurements on thin sections: numerical modeling. American Mineralogist, 79, 113119.

Higgins, M.D.: 1996, Magma dynamics beneath Kameni Volcano, Greece, as revealed by crystal size and shape measurements. Journal of Volcanology and Geothermal Research, 70, 37-48.

DOI: $10.1016 / 0377-0273(95) 00045-3$

Higgins, M.D.: 1998, Origin of anorthosite by textural coarsening: quantitative measurements of a natural sequence of textural development. Journal of Petrology, 39, 1307-1325. DOI: $10.1093 /$ petroj/39.7.1307

Higgins, M.D.: 2000, Measurement of crystal size distributions. American Mineralogist, 85, 1105-1116.

Higgins, M.D.: 2002, A CSD study of the Kiglapait layered mafic intrusion, Labrador, Canada: evidence for textural coarsening. Contributions to Mineralogy and Petrology, 144, 314-330. DOI: $10.1007 / \mathrm{s} 00410-002-0399-9$

Kohnavard, M.: 2015, Zanbil volcanic rokes petrology. B.Sc. thesis; Urmia University, Iran, (in Persian).

Kretz, R.: 1966, Grain-size distribution for certain metamorphic minerals in relation to nucleation and growth. The Journal of Geology, 74, 147-173. DOI: $10.1086 / 627152$

Maaloe, S., Tumyr, O. and Dodie, J.: 1989, Population density and zoning of olivine phenocrysts in tholeiites from Kauai, Hawaii. Contributions to Mineralogy and Petrology, 101, 176-186. DOI: 10.1007/BF00375304

Mangan, M.T.: 1990, Crystal size distribution systematics and the determination of magma storage times: The 1959 eruption of Kilauea volcano, Hawaii. Journal of Volcanology and Geothermal Research, 44, 295-302. DOI: $10.1016 / 1377-0273(90) 90023-9$

Marsh, B.D.: 1988, CSD in rocks and the kinetics and dynamics of crystallization. I Theory. Contributions to Mineralogy and Petrology, 99, 277-291. DOI: $10.1007 / \mathrm{BF} 00375363$

Marsh, B.D.: 1998, On the interpretation of CSD in magmatic systems. Journal of Petrology, 39, 553-600. DOI: $10.1093 /$ petroj/39.4.553

Moazzen, M. and Modjarrad, M.: 2005, Contact metamorphism and CSD studies in the Shivar aureole, NW, Iran. Geological Journal, 40, 499-517. DOI: $10.1002 /$ gj. 1025

Mock, A. and Jerram, D.A.: 2005, CSD in three dimensions: insights from the 3D reconstruction of a highly porphyritic rhyolite. Journal of Petrology, 18, 1-17. DOI: 10.1093/petrology/egi024

Modjarrad, M.: 2015a, Crystal size distribution of amphiboles from Bezow dacites, Urmia, Iran. N. Jb. Geol. Palaont. Abh, 276/1, 101-110. DOI: http://dx.doi.org/10.1127/njgpa/2015/0482 
Modjarrad, M.: 2015b, Geochemistry of Bezow-Daghi area volcanic rocks, Urmia; Adakitic magmatism at the Urmia-Dokhtar magmatic belt. Petrology, (in Persian), in press.

Modjarrad, M. and Shaykhbaglou, S.: 2015, Crystal size distribution of kyanite and staurolite from Hamza Qassim and Khazai Bala Metapelites - Southeast Shahin-Dezh. Iranian Journal of Crystallography and Mineralogy (in Persian), in press.

Morgan, D.J. and Jerram, D.A.: 2006, On estimating crystal shape for crystal size distribution analysis. Journal of Volcanology and Geothermal Research, 154, 1-7. DOI: 10.1016/j.jvolgeores.2005.09.016

Murphy, M.D., Sparks, R.S.J., Barclay, J., Carroll, M.R. and Brewer, T.S.: 2000, Remobilisation of andesitic magma by intrusion of mafic magma at the Soufriere Hills volcano, Montserrat, West Indies. Journal of Petrology, 41, 21-42. DOI: 10.1093/petrology/41.1.21

Nkono, C., Femenias, O., Diot, H., Berza, T. and Demaiffe, D.: 2006, Flowage differentiation in an andesitic dyke of the Motru Dyke Swarm (Southern Carpathians, Romania): Evidence from AMS, CSD and geochemical investigations. Journal of Volcanology and Geothermal Research, 154, 201-22. DOI: 10.1016/j.jvolgeores.2006.02.011

Peterson, T.D.: 1996, A refined technique for measuring CSD in thin section. Contributions to Mineralogy and Petrology, 124, 395-405. DOI: $10.1007 / \mathrm{s} 004100050199$

Sparks, R., Sigurdsson, H. and Wilson, L.: 1977, Magma mixing: a mechanism for triggering acid explosive eruptions. Nature, 267, 315-318. DOI: $10.1038 / 267315 \mathrm{a} 0$

Spillar, V. and Dolejz, D.: 2013, Calculation of timedependent nucleation and growth rates from quantitativetextural data: Inversion of crystal size distribution. Journal of Petrology, 54 (5), 913-931. DOI: 10.1093/petrology/egs091

Sunagawa, I.: 1987, Morphology of crystals. Riedel, Dordrecht, $743 \mathrm{pp}$.
Voorhees, P.W.: 1992, Ostwald ripening of two-phase mixtures. Annual Review of Materials Science, 22, 197-215.

DOI: 10.1146/annurev.ms.22.080192.001213

Waters, C. and Boudrea, A.E.: 1996, A reevaluation of CSD in chromite cumulate. American Mineralogist, 81, 1452-1459. DOI: 0003-004X/96/1 I 12-1452\$05.00

Wilhelm, S. and Worner, G.: 1996, CSD in Jurassic Ferrar flows and sills: evidence for processes of cooling, nucleation and crystallization. Contributions to Mineralogy and Petrology, 125, 1-15. DOI: $10.1007 / \mathrm{s} 004100050202$

Yu, H., Xu, J., Lin, C., Shi, L. and Chen, X.: 2012, Magmatic processes inferred from chemical composition, texture and crystal size distribution of the Heikongshan lavas in the Tengchong volcanic field, SW China. Journal of Asian Earth Sciences, 58, 1-15. DOI: 10.1016/j.jseaes.2012.07.013

Yu, H., Xu, J., Zhao, B., Shen, H. And Lin, C.: 2014, Magmatic processes of Ashi Volcano, Western Kunlun Mountains, China. Acta Geologica Sinica, 88, 530-543. DOI: 10.1111/1755-6724.12212

Zellmer, G.F., Blake, S., Vance, D., Hawkesworth, C. and Turner, S.: 1999, Plagioclase residence tines at two island arc volcanoes determined by $\mathrm{Sr}$ diffusion systematic. Contrib Mineral Petrol, 136, 345-357. DOI: $10.1007 / \mathrm{s} 004100050543$

Zieg, M.J. and Marsh, B.D.: 2002, CSD and scaling laws in the quantification of igneous textures. Journal of Petrology, 43, 85-101. DOI: $10.1093 /$ petrology/43.1.85 